\title{
HEALTH CARE LOGISTICS: MAPPING AND OPTIMIZATION OF PATIENTS LOGISTICS
}

\author{
Daiane Maria de Genaro Chiroli \\ Universidade Tecnológica Federal do Paraná, Brazil \\ E-mail:dmgenaro@hotmail.com \\ Raźa Conde Coradazi \\ Universidade Tecnológica Federal do Paraná, Brazil \\ E-mail: raiza.conde.coradassi@hotmail.com \\ Fabio Jose Ceron Branco \\ Universidade Tecnológica Federal do Paraná, Brazil \\ E-mail: fbranco@utfpr.edu.br \\ Yslene Rocha Kachba \\ Universidade Tecnológica Federal do Paraná, Brazil \\ E-mail: yslener@utfpr.edu.br \\ Franciely Velozo Aragão \\ Universidade Tecnológica Federal do Paraná, Brazil \\ E-mail: fran-aragao@hotmail.com \\ Fernanda Cavicchioli Zola Cavicchioli Zola \\ Universidade Tecnológica Federal do Paraná, Brazil \\ E-mail: fzola@utfpr.edu.br \\ Sergio Mazurek Tebcherani \\ Universidade Tecnológica Federal do Paraná, Brazil \\ E-mail:sergiom@utfpr.edu.br \\ Tiberio Bruno Rocha E Cruz \\ Universidade Tecnológica Federal do Paraná, Brazil \\ E-mail: cruz.rocha.bruno@gmail.com
}

Submission: 12/2/2020

Revision: 12/15/2020

Accept: 1/5/2021

\section{ABSTRACT}

Healthcare logistics play an important role in management, being attributed the activities of acquisition, distribution and movement of materials, professionals and patients. This work aims to develop a study, using the healthcare logistics in the movement of patients in the third health region of Paraná, proposing a linear programming problem that will pass through a computational simulation, considering the existing demands and constraints in the system, aiming to 
DOI: 10.14807/ijmp.v12i8.1510

optimize the flow of patients from this region. The present study developed four mathematical models, based on demands and constraints followed by linear programming in order to find the best possible solution for the flow of patients from the third health region of the state of Paraná. The study developed reached its goal of optimization, generating an economy in the transportation of patients. Through the analysis of the results, it is concluded that the model that best suits the presented problem is the one of costs minimization, since the one of vehicles presented higher costs. Possibly the model that minimizes the vehicles would bring better results if the vehicles were not outsourced, but of the Ponta Grossa City Hall (PMPG). Was possible to verify the importance of the theme, especially when referring to the flow of patients in the health services due to the lack of studies with this specific approach. Even with the scarcity of data, it is possible to notice the potential for improvements on this patient transport system.

Keywords: Healthcare logistics; Health services; Flow of patients; Optimize; Linear Programming Problem

\section{INTRODUCTION}

Logistics aims to provide the availability of products and / or services where and when they are needed (Chiroli et al., 2016). A basic question of logistics management is how to structure systems and configurations that are capable of economically serving markets distant from production sources, offering high levels of service in terms of availability and serviceability in ever shorter time periods (Ballou 1993, 2003).

Although many logistical studies focus on the logistical response over uncertainty (Babazadeh et al., 2014), it can be said that commercial logistics is different from logistics in health services. This refers to the different conditions they face, both of which seek to optimize costs, planning, quality, control and organization (Gul \& Guneri, 2016).

However, in the logistics of health services it is necessary to take into account specific characteristics that characterize its complexity, being: integral involvement with the client, risks of sudden variations in the processes, variability and complexity of services rendered and unstable demand (Mathias et al., 2005; Piccirillo et al., 2016).

Health logistics is an even greater challenge in the event of a disaster or epidemic, where the response time needs to be even more efficient in order to save lives (Gao et al., 2017). COVID 19 was detected with pneumonia in China in 2019, however, within 10 weeks there 
INDEPENDENT JOURNAL OF MANAGEMENT \& PRODUCTION (IJM\&P)

http://www.ijmp.jor.br

v. 12, n. 8, November-December 2021

ISSN: $2236-269 X$

DOI: 10.14807/ijmp.v12i8.1510

were already millions of cases worldwide. Thus, the World Health Organization (WHO) declared a global pandemic of COVID 19 on 11 March 2020, going from more than three million cases worldwide to 27 April (Bergquist and Stensgaard, 2020).

In times of pandemic where the transmission of a virus can be fatal in patients with preexisting diseases such as the case of COVID 19. In this new reality, the planning and organization of the health logistics service has to be better designed and improved with the intuited to increasingly ensure the health of the patient and the people who have direct contact with him even during the necessary journey. The transport of patients with COVID 19 to Yousuf et al., (2020) is divided into five phases: transport equipment to be pre-arranged; preparations before transport; transport process; after arrival.

However, it was not found in the literature how to transport a sick patient, but not with COVID, but with other diseases that need specialized care and cannot have counted on people who have COVID, because they are at risk group where contamination can be fatal. The difficulty of transporting this patient is greater in patients who need free health care offered by the government, as is the case with a large part of the Brazilian poor population.

If health logistics in times of pandemic is extremely important, because it is carried out in the correct way (with protective actions for patients, a health team and hygiene of the transport vehicle) whether in the public or private organization, it can minimize the contamination of patients and the health team and, as a consequence, a lower number of deaths caused by COVID 19.

For public management, in the federal, state and municipal spheres, the challenge is to provide quality, safe and at the right time health services to the citizen. In order to comply with the principles of legality, quality, economy and speed, offering the service on time and adequate amounts to save lives (Aragão et al., 2020; Coêlho, 2010).

Organizations are embedded in a scenario where costs are increasingly higher, there is a demand for higher quality and more productivity is required (Dussault, 1992). In this way it is necessary to provide people each time more with the amount of resources available. In public health, logistics for having specific characteristics should have an approach focused not exclusively on cost rationalization, it must be treated as an element of fundamental support to the health services provided to patients. Though, in times of a pandemic with viral transmission, the difficulty is at low cost, but it still guarantees the health of the patient transported to carry out his treatment. 
DOI: 10.14807/ijmp.v12i8.1510

To improve service levels, it is necessary to maximize the coherence between resources and services, which must be balanced, without excesses or shortages (Coêlho, 2010). This implies eliminating geographical imbalances (services must be available wherever they are needed), numerical (human health) and organizational (a balance between basic and hospital services is required).

For the Ministry of Health (BRASIL, 2006) regionalization is a proposal that aims to organize and divide the cities of the state in order to allow and facilitate the displacement of patients who need it. Because, the Brazil is a country with a very large geographic extension and there is no specialized health care in all regions, so the Brazilian population needs to travel to have this care.

There is a political component that is not intended to be annulled with this study, but it is important the planning and the technical decisions that can make possible good use of the public money. To better allocate the health resources of the Paraná State, SESA (State Health Department of Paraná) prepared the state regionalization plan that separated the 399 counties into 4 macro-regions and 22 health regions, to allow and facilitate the displacement of patients who need specific care in others counties. In this sense, people who need specific health care treatment that is not offered in their respective cities, are transported to the health centers of the macro-regions, to obtain specified medical care.

Characterize the problematic of logistics in healthcare this study aim is to develop, from the data collection, a linear programming problem that optimizes the logistics of patients from the 3rd Region of Health from the state of Paraná, seeking to use the available resources efficiently. A 3rd Region of Health from the state of Paraná known as “Campos Gerais” comprises 12 cities and an average population of 725.749 inhabitants. Being the largest Ponta Grossa city with 351.736 inhabitants and with a better hospital structure than other municipalities.

\subsection{Logistics in Health Services}

Since the mid-1960s, health services have come to be regarded as a scientific area (Bindman, 2013). This is due to the need for improvements in planning, control and quality of the services provided to the patients; greater efficiency and quality improvement should be sought with the minimization of costs (Ying \& Kittipittayakorn, 2018).

Health services have changed over the years, several operating and management areas have been introduced to meet the requirements of activities such as acquisition, movement and 
INDEPENDENT JOURNAL OF MANAGEMENT \& PRODUCTION (IJM\&P)

http://www.ijmp.jor.br

v. 12, n. 8, November-December 2021

ISSN: 2236-269X

DOI: 10.14807/ijmp.v12i8.1510

distribution of supplies and equipment. Such activities aim to improve the services provided and the satisfaction of clients, in this case, patients. This requires agility in the supply of inputs and operational activities essential for patients' recovery (Rodrigues and Sousa, 2014). In table 1, it's shown the work carried out in the healthcare logistics area.

Table 1. Literary review of the logistics approach in health services

\begin{tabular}{|c|c|c|}
\hline Title (Author and Year) & Approach & Focus \\
\hline $\begin{array}{l}\text { Hospital Pharmacy } \\
\text { Management: Optimizing } \\
\text { Quality, Productivity, and } \\
\text { Financial Resources } \\
\text { (Barbosa, 2015). }\end{array}$ & $\begin{array}{l}\text { The approach refers to the } \\
\text { administration of medicines and } \\
\text { materials in hospital pharmacies, } \\
\text { highlighting their importance to the } \\
\text { operation of the hospital and the } \\
\text { failure in this management can lead } \\
\text { to irreparable losses to the patient's } \\
\text { health. }\end{array}$ & $\begin{array}{l}\text { Administration of medicines and } \\
\text { materials }\end{array}$ \\
\hline $\begin{array}{l}\text { The coordination of } \\
\text { allocation: Logistics of } \\
\text { kidney organ allocation to } \\
\text { highly sensitized patients } \\
\text { (Lunz et al. 2016). }\end{array}$ & $\begin{array}{l}\text { The study addresses the logistics of } \\
\text { renal organ allocation and } \\
\text { coordination in order to minimize } \\
\text { the time for transplantation. }\end{array}$ & $\begin{array}{l}\text { Flow and coordination of } \\
\text { materials (organs) }\end{array}$ \\
\hline $\begin{array}{l}\text { Hybridization of tabu search } \\
\text { with feasible and infeasible } \\
\text { local searches for periodic } \\
\text { home health care logistics } \\
\text { (Liu et al. 2014). }\end{array}$ & $\begin{array}{l}\text { Logistics is approached from the } \\
\text { perspective of home health care. A } \\
\text { model has been developed for } \\
\text { vehicle routing to meet the demands } \\
\text { of drug transport (patient's depot } \\
\text { and home), delivery of special } \\
\text { medicines (from hospital to patient) } \\
\text { and delivery of blood samples } \\
\text { (patient's home to laboratory), to } \\
\text { minimize the total cost. }\end{array}$ & $\begin{array}{l}\text { Flow of medicines and materials; } \\
\text { Vehicle Routing. }\end{array}$ \\
\hline $\begin{array}{l}\text { Medication and material } \\
\text { logistics in a public hospital } \\
\text { in the Federal District } \\
\text { (Raimundo et al., 2014). }\end{array}$ & $\begin{array}{l}\text { Logistics in health services under } \\
\text { the management of the flow of } \\
\text { materials and medicines, } \\
\text { highlighting the importance of } \\
\text { information systems that should be } \\
\text { appropriate to hospital } \\
\text { environments. }\end{array}$ & $\begin{array}{l}\text { Flow of medicines and materials; } \\
\text { Information flow. }\end{array}$ \\
\hline $\begin{array}{l}\text { A case study of collaborative } \\
\text { communications within } \\
\text { healthcare logistics } \\
\text { (Vanvactor, 2011). }\end{array}$ & $\begin{array}{l}\text { The study addresses the importance } \\
\text { of supply chain management in } \\
\text { health services, and how } \\
\text { communication strategies affect the } \\
\text { chain. It highlights the importance } \\
\text { of coordination between public } \\
\text { services and government agencies to } \\
\text { perform these services. }\end{array}$ & $\begin{array}{c}\text { Supply chain } \\
\text { management;Information flow. }\end{array}$ \\
\hline $\begin{array}{l}\text { The organization of public } \\
\text { hospital supply from the } \\
\text { supply chain: a logistical } \\
\text { approach to healthcare } \\
\text { (Infante and Santos, 2007). }\end{array}$ & $\begin{array}{l}\text { Health services are seen as a chain, } \\
\text { focused on the supply problem, an } \\
\text { integrated system of organization } \\
\text { and programming of inputs was } \\
\text { developed involving external } \\
\text { partners highlighting the partnership } \\
\text { with suppliers. }\end{array}$ & Supply chain management; \\
\hline $\begin{array}{l}\text { Scheduling logistic activities } \\
\text { to improve hospital supply } \\
\text { systems (Lapierre and Ruiz, } \\
\text { 2007). }\end{array}$ & $\begin{array}{l}\text { In the study, mathematical models } \\
\text { were used to coordinate the } \\
\text { purchase, material distribution and } \\
\text { inventory operations. }\end{array}$ & $\begin{array}{l}\text { Supply chain management; } \\
\text { Materials Management }\end{array}$ \\
\hline
\end{tabular}


INDEPENDENT JOURNAL OF MANAGEMENT \& PRODUCTION (IJM\&P)

http://www.ijmp.jor.br

v. 12, n. 8, November-December 2021

ISSN: 2236-269X

DOI: 10.14807/ijmp.v12i8.1510

\begin{tabular}{|c|c|c|}
\hline $\begin{array}{c}\text { Strategy deployment in } \\
\text { healthcare services: A case } \\
\text { study approach (Landry et } \\
\text { al. 2016). }\end{array}$ & $\begin{array}{l}\text { Logistics should be treated as a } \\
\text { strategic resource in health services } \\
\text { because their effective management } \\
\text { optimizes available time and } \\
\text { resources thereby increasing } \\
\text { efficiency. }\end{array}$ & Logistics as a strategy \\
\hline $\begin{array}{l}\text { Methodology of emergency } \\
\text { medical logistics for public } \\
\text { health emergencies (He and } \\
\text { Liu, 2015). }\end{array}$ & $\begin{array}{l}\text { Logistics in health services are } \\
\text { addressed in relation to emergency } \\
\text { care, methods are proposed for rapid } \\
\text { response to public emergency care. }\end{array}$ & Routing; Flow of patients \\
\hline $\begin{array}{l}\text { A framework to analyze } \\
\text { hospital-wide patient flow } \\
\text { logistics: Evidence from an } \\
\text { Italian comparative study } \\
\text { (Villa et al. 2014). }\end{array}$ & $\begin{array}{l}\text { Through a comparative study } \\
\text { between Italian hospitals, a patient } \\
\text { flow performance analysis was } \\
\text { performed throughout the hospital, } \\
\text { where it was structured at the } \\
\text { hospital levels, possible patient } \\
\text { travel and physical spaces } \\
\text { (operating room). }\end{array}$ & Flow of patients \\
\hline $\begin{array}{c}\text { Health service optimization } \\
\text { in the state of Paraná: patient } \\
\text { flow and new hierarchical } \\
\text { configurations (Scarpin et } \\
\text { al. 2007). }\end{array}$ & $\begin{array}{l}\text { The study proposes a hierarchical } \\
\text { configuration, a division of the state } \\
\text { to optimize the flow of patients in } \\
\text { relation to movement, where they } \\
\text { need to move from the city of origin } \\
\text { to receive care in another city. }\end{array}$ & Flow of patients \\
\hline $\begin{array}{l}\text { Exploring improvements in } \\
\text { patient logistics in Dutch } \\
\text { hospitals with a survey (Lent } \\
\text { et al. 2012). }\end{array}$ & $\begin{array}{l}\text { The total route of a patient in the } \\
\text { health care system is specific and } \\
\text { depends on their health. We } \\
\text { conclude that patient logistics can } \\
\text { be considered as an element of } \\
\text { efficiency and punctuality in the } \\
\text { definition of quality. }\end{array}$ & Patient flow in hospitals \\
\hline $\begin{array}{l}\text { Safe patient transport for } \\
\text { COVID-19 (Lew, et al. } \\
\text { 2020). }\end{array}$ & $\begin{array}{l}\text { The study presents better ways to } \\
\text { transport COVID } 19 \text { patients, either } \\
\text { inside or outside the hospital, } \\
\text { through six phases. }\end{array}$ & Flow of patients \\
\hline
\end{tabular}

From the literary review it is possible to notice that the logistics in the health services is presented as something fragmented, without taking into account the logistic functions, each author presents a different and limited approach. The authors' approach can be divided into: Management of the flow of medicines and materials; Supply Chain Management, Information Flow; Logistics as strategy and Flow of patients.

The approach most found in the development of studies is the Flow management of materials, where (Barbosa, 2015; Lunz et al., 2016; Liu et al., 2014; Raimundo et al., 2014) present this approach. The logistics approached, from the point of view of supply chain management and information flow, is addressed by Vanvactor, (2011), Infante and Santos, (2007) and Lapierre and Ruiz, (2007), even though the focus is the same, each author approaches the supply chain in a different way, whether focusing on the importance of information flow or the management of materials. A different approach is addressed by Landry et al., (2016), because for the author, logistics should be viewed strategically by health service 
DOI: 10.14807/ijmp.v12i8.1510

organizations and should be used to achieve their goals. Finally, the flow of patients, focus of this study, is approached in different ways by the authors.

In the patient flow approach, the authors present different perspectives for these cases, that is, the flow of patients is studied taking into account isolated cases of the problem. In the study of He and Liu (2015) the flow of patients is studied in relation to the emergency care, in the study Villa et al.,(2014) the flow is evaluated internally, that is, inside the hospitals, considering its necessary movement within the hospital or its physical units. The study that is closest to the one proposed in this study is of Scarpin et al.,(2007) in which the authors propose a hierarchical division of the state of Paraná to optimize the flow of patients treated by the Unified Health System in the state. From this division a mathematical modeling was performed considering the constraints of time, capacity and precedence to arrive at the best route possible for the flow of the patients.

In the literary revision it's possible to notice the there isn't a definition for logistics in healthcare, what makes more difficult its understanding. In this way, it's necessary to consider the concepts related to provision of services and then seek to adopt and develop them to the problematic of logistics in healthcare and its focus on optimization.

For Careta (2013) must be considered that the health services are different from the manufacturing, that is, in the health services what is processed is the patient, in this way, logistics should be analyzed in a different way for this specific case. For the authors, the focus of logistics management should be related to the flow of patients.

In services, it is necessary to distinguish inputs and resources, thus, in services the inputs are the customers themselves and the resources refer to the facilitating goods (labor and capital available). Therefore, for a service system to work, it must consider the customer as part of the service process (Masmoudi et al., 2018).

The definition of Fitzsimmons and Fitzsimmons (2010) justifies the previous statement of Careta (2013), from this it can be seen that especially in the provision of health services the client, who in this case is the patient, should be included as part of the process, therefore, the patient must be involved in all stages of planning, management and operation. As it is published in the transport phases for patients of COVID by the authors (Liew et al., 2020) where the first phase is already in the patient's health, after the prevention of non-contamination of everyone involved in the transport of patients as the second phase. 
DOI: 10.14807/ijmp.v12i8.1510

\section{MATERIALS AND METHODS}

The present study aims to develop a mathematical model, based on demands and constraints followed by linear programming to find the best possible solution for the flow of patients from the third health region of the state of Paraná. To reach this problem, an exploratory study was developed, based on research in periodicals, articles, books, annals of congresses and specialized journals in order to identify studies already carried out and aspects addressed in relation to the theme.

The development of the study consisted in the execution of 5 steps: data collection, definition of constraints, mathematical modeling of linear programming, computational simulation, feasibility of the solution and, finally, the discussions.

Data collection took place with the government of Ponta Grossa / PR. With the project it was possible to have access to the internal data and carry out field analysis of the operation of patient logistics. The following data were collected: distances, transportation costs, specialty demand, average kilometers traveled, number of cars and hospitals, number of drivers / professionals, precedence chart and average travel time.

Ordinance No. 55 of February 24, 1999 provides that patients who are exhausted from offered treatment within the county where they reside are referred for treatment in another city that meets their needs. Based on this principle, in Paraná there is the State Regionalization Plan, elaborated in 2001 and revised in 2009 and 2015, which aims to decentralize health care within the state. In this plan, to divide health care, the state of Paraná is divided into 4 Macroregions, which are subdivided into 22 Health Regions and the city of Ponta Grossa; the focus of this study, it belongs to the 3rd Health Region, together with more of 12 counties, which cover a population of approximately 570 thousand people (Brasil, 2006).

According to data and information collected, approximately 30,000 passengers are transported per year, among patients and caregivers who need transportation to out-of-home care. The destinations include the cities of Maringá, Londrina, Pato Branco, Cascavel, Curitiba, Campo Largo, Campina Grande do Sul and Piraquara shown in Figure 1. 
DOI: $10.14807 /$ ijmp.v12i8.1510

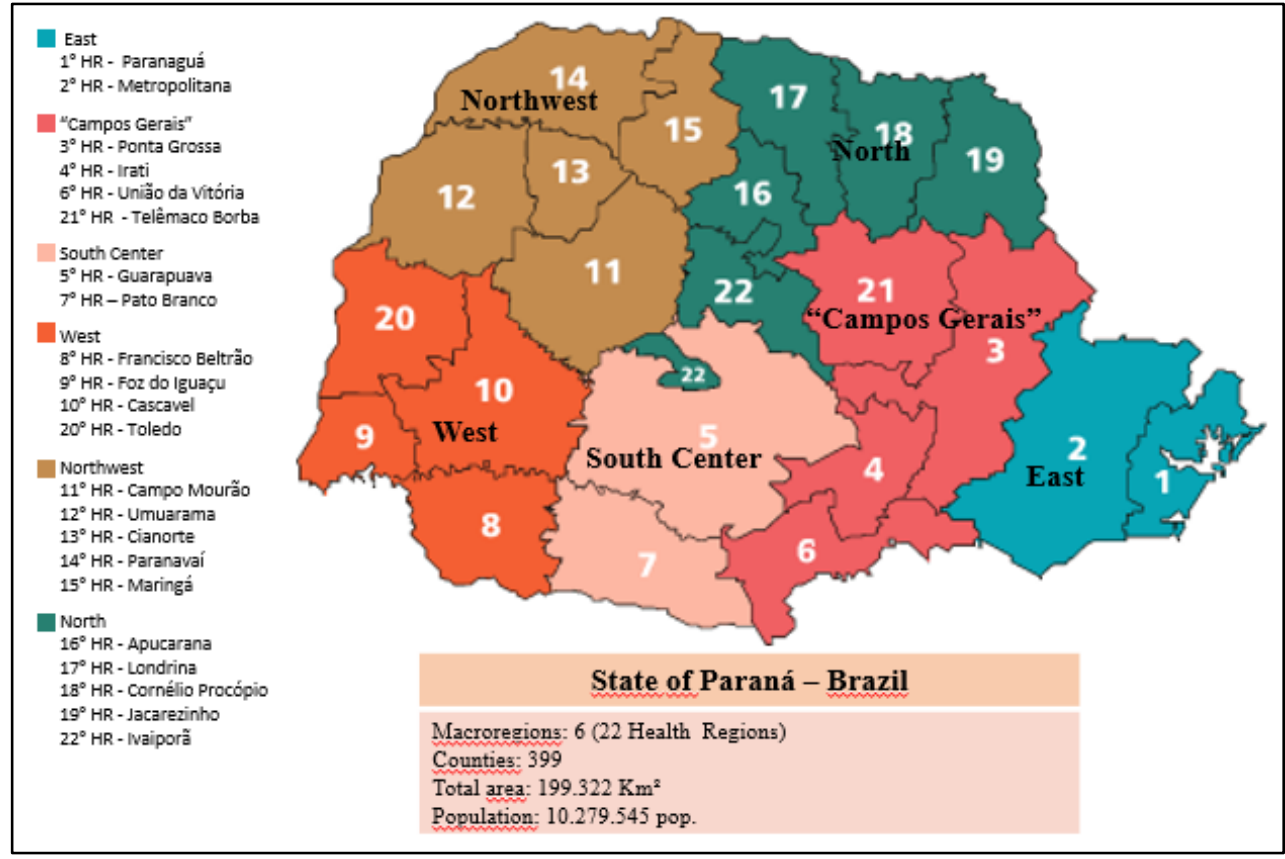

Figure 1: Health regional organizations in the state of Paraná - Brazil

Each destination serves a service of different complexity. The city of Curitiba and nearby serve the specialties that patients cannot find in the city of Ponta Grossa. The cities of Maringá and Cascavel meet the demand for specialized psychiatric care, Londrina is a reference for the care of burned and Pato Branco for kidney transplantation. Among the destinations, the city of Curitiba and the counties of the region (Campo Largo, Campina Grande do Sul and Piraquara) are the ones that concentrate the greatest demand for patients. The other destinations have a specific demand, and for this reason the study focused on optimizing the transportation of patients and companions on the way to capital and surroundings.

The demands of patients and passengers in recent years have been a minimum of 11914 patients and 7414 companions and a maximum of 16171 patients and 9960 companions. The separation between patients and caregivers is due to the need that exists when the patient is over 60 years or less than 18 years old, people with special needs, people with disabilities or who will undergo a surgical procedure, and in these cases, the patient has the right to bring a companion. With the increase in COVID cases in the state of Paraná, the right to a companion was prohibited, reducing the demand for passenger transport.

In order to carry passengers to the destinations, the City Office outsources transportation, chartering buses and vans according to the demands presented; it owns 4 cars and 3 ambulances. For Curitiba and neighboring cities, buses, vans and cars are used, since ambulances are used for transfers and specific cases when there is a medical request and justification of the necessity of its use, in order to avoid unnecessary uses that may prevent it 
INDEPENDENT JOURNAL OF MANAGEMENT \& PRODUCTION (IJM\&P)

http://www.ijmp.jor.br

v. 12, n. 8, November-December 2021

ISSN: $2236-269 X$

DOI: 10.14807/ijmp.v12i8.1510

from being available for situations of real need. Although the role of public health is to watch over the health of the population and give decent treatment to everyone, as imposed in Brazil Federal Constitution of Brazil of 1988, the city hall must also make effective use of the financial resources that are distributed to all city offices.

In this way, SESA (2015) seeks to solve the problem of the flow of patients who need to travel to another city to receive the medical care they need. The referral of the patient to the specific health care must take place in a fast and safe way, in addition to optimizing the use of resources (vehicles and employees) and minimizing the spent time in order to reduce the risks of worsening the patients' health. The health sector needs many resources and if it is capable to improves the use of this resource, the surplus can be used for other actions such as hiring more doctors and equipment purchases that will support more health specialists. Thus, this paper focused on minimizing transport costs for inter-municipal patients.

The daily costs per hired vehicle and/or used estimated by the government of Ponta Grossa are: bus, cost of \$ 324; van, \$162; and car, \$ 73. Currently, the average monthly expenses with bus charter, according to the Ponta Grossa city Hall (PMPG) is around \$ 12973 and with vans \$ 6486. The costs for the cars and ambulances added correspond to approximately $\$ 8108$, in this cost are included the 6 car drivers and 7 ambulance drivers that work in scale of 24 hours. This totals an average monthly cost of \$ 27568.

After the data collection, the constraints for the development of the linear programming problem were defined. With the model, the computer simulation followed. To accomplish this, the Excel solver tool was chosen, which provides the resources needed to solve the problem proposed.

In the stage of viability of the solution found, the results obtained were compared with the objectives of the study development to determine if these were reached. Abbreviations that are used for the first time in the text must be defined.

\section{RESULTS}

In this chapter, it will be presented the mathematical modeling in order to optimize the health care logistical costs of patients. It is important to emphasize that in this paper it was considered that the patient screening was performed previously and there is no specialized health care in the patient's city, thus there is a need to use the vehicles provided by the city hall. It is also important to note that there are priorities for patients due to the level of health severity. Therefore, if the patient needs emergency care, he is directed to use the ambulance 
DOI: 10.14807/ijmp.v12i8.1510

that will send him to the city that has specialized assistance. For elective patients, who need assistance without urgency, a travel schedule is possible. Thus, PMPG also analyzes the cost of hiring vehicles, aiming for the optimization of this resource.

\subsection{Mathematical models for optimization}

In order to offer a solution that optimizes the presented problem, four mathematical models were elaborated to approach the problem from different perspectives so that, when comparing results, we choose the model that offers the best optimization, bringing greater benefits to the system. In the models simulations, the daily demand of 110 passengers was considered (it was considered 5 days of the week, from Monday to Friday, that is, 22 days a month), this demand was estimated from the average of the growth percentage number of patients per year.

\subsection{Model 1: Minimization of the Quantity of Vehicles}

In this model, the objective function consists in minimizing the number of vehicles used to transport passengers, offering the mix of vehicles that meets the demand and the objective function. The following decision variables were used that represent the quantity of each type of vehicle $O, V, C$, being bus, van and car respectively; and $c p_{o}, c p_{v}, c p_{c}$ represent the capacities of each of the vehicles; the letter $D$ symbolizes the passenger demand.

$$
\operatorname{Min} z=O+V+C
$$

OSubject to:

$$
\begin{aligned}
& O c p_{o}+V c p_{v}+C c p_{c} \geq D \\
& c p_{o} \leq 44 \\
& c p_{v} \leq 20 \\
& c p_{c} \leq 4 \\
& C \leq 4 \\
& O, V, C \geq 0 \text { and integer }
\end{aligned}
$$

In restriction (2) it's represented the need to meet passengers demand. The restrictions (3), (4) and (5) are related to the passengers' capacity of each of the vehicles, the bus has a 
ISSN: 2236-269X

DOI: 10.14807/ijmp.v12i8.1510

capacity of 44 passengers, the van of 30 passengers and the car of 4 passengers, and restriction (6) is due to the quantity of the city's own cars available. Finally, the restriction (7) is to be nonnegative and integer. Table 2 shows the simulation results of model 1.

Table 2: Simulation Result of Model 1

\begin{tabular}{|c|c|c|c|c|c|c|c|}
\hline \multicolumn{2}{|c|}{$\begin{array}{l}\text { Among of each } \\
\text { type of vehicle }\end{array}$} & Capacity & Total & $\begin{array}{c}\text { Transport } \\
\text { cost }\end{array}$ & Cost & $\begin{array}{c}\text { Total of } \\
\text { empty seat }\end{array}$ & $\begin{array}{c}\text { Empty } \\
\text { seats max }\end{array}$ \\
\hline Bus & 3 & 44 & 132 & $\$ 324,32$ & $\$ 972,97$ & \multirow{4}{*}{$x_{2}$} & \multirow{4}{*}{17} \\
\hline Van & 0 & 20 & 0 & $\$ 162,26$ & & & \\
\hline Car & 0 & 4 & 0 & $\$ 72,97$ & & & \\
\hline Total & 3 & $\begin{array}{c}\text { Total of } \\
\text { passengers }\end{array}$ & 132 & Total & $\$ 972,97$ & & \\
\hline
\end{tabular}

As a result of the minimization simulation of vehicles, there is the amount of 3 daily buses to meet the patients' demand. The cost of this solution would be $\$ 973$ per day, another point of attention is the amount of empty sits that this solution provides, a total of 22. The solution is that for protection against the non-transmission of COVID 19 it can be indicated because we would have only one passenger for every two seats.

\subsection{Model 2: Cost Minimization using Total Own Fleet}

The following model aims to minimize the costs of passenger transportation (patients and companions) by providing the optimal mix of quantity and type of vehicles to meet passenger demand. What differs this model from the previous one, besides the objective function, was the inclusion of restrictions to try to guarantee a better optimization of the results.

$$
\operatorname{Min} z=O c t_{o}+V c t_{v}+C c t_{c}
$$

Subject to:

$$
\begin{aligned}
& \left(O c p_{o}+V c p_{v}+C c p_{c}\right)-D \leq 0,15\left(O c p_{o}+V c p_{v}+C c p_{c}\right) \\
& O c p_{o}+V c p_{v}+C c p_{c} \geq D \\
& O c t_{o}+V c t_{v}+C c t_{c} \leq O d \\
& c p_{o} \leq 44 \\
& c p_{v} \leq 20 \\
& c p_{c} \leq 4
\end{aligned}
$$


$O, V, C \geq 0$ and integer

In this model there are 3 new constants, these being $c t_{o}, c t_{v}, c t_{c}$, which represent the costs of each of the types of vehicles available for use. In Model 2, it is also considered a daily budget available represented by Od, this restriction is represented in equation (4), it was also included restriction (2) that has the objective of limiting the number of empty sits by $15 \%$ for better use of the available seats. The other restrictions remain as in Model 1. This number of empty seats in vehicles was defined by the fact that there is a need for the return of patients who were hospitalized in the served cities and were discharged. In Table 3 the results of this simulation are shown.

Table 3: Simulation Result of Model 2

\begin{tabular}{|c|c|c|c|c|c|c|c|c|c|}
\hline \multicolumn{2}{|c|}{$\begin{array}{l}\text { Among of } \\
\text { each type of } \\
\text { vehicle }\end{array}$} & Capacity & Total & $\begin{array}{l}\text { Daily } \\
\text { demand }\end{array}$ & $\begin{array}{c}\text { Daily } \\
\text { Bdudget }\end{array}$ & $\begin{array}{c}\text { Transport } \\
\text { cost }\end{array}$ & Cost & $\begin{array}{c}\text { Total of } \\
\text { empty } \\
\text { seat }\end{array}$ & $\begin{array}{c}\text { Empty } \\
\text { seats } \\
\text { max }\end{array}$ \\
\hline Bus & 2 & 44 & 88 & \multirow{4}{*}{110} & \multirow{4}{*}{$\$ 1.013,51$} & $\$ 324,32$ & $\$ 648,65$ & \multirow{4}{*}{2} & \multirow{4}{*}{17} \\
\hline Van & 1 & 20 & 20 & & & $\$ 162,26$ & $\$ 162,26$ & & \\
\hline Car & 1 & 4 & 4 & & & $\$ 72,97$ & $\$ 72,97$ & & \\
\hline Total & 4 & $\begin{array}{c}\text { Total of } \\
\text { passangers }\end{array}$ & 112 & & & Total & $\$ 883,88$ & & \\
\hline
\end{tabular}

It is possible to verify that there were improvements in relation to the results obtained from Model 1, one of them with regards to the number of vacant sits, which was reduced by 20. Another point is the cost, which to meet the same demand, Model 1 would have an additional cost of $\mathrm{R} \$ 330.00$; even more significant when considering the accumulated value.

\subsection{Model 3: Costs Minimization using Partial Own Fleet}

Model 3 has the same objective function and restrictions of Model 2, but there is a change in the number of cars available for use in passengers transport.

$$
\operatorname{Min} z=O c t_{o}+V c t_{v}+C c t_{c}
$$

Subject to:

$$
\begin{aligned}
& \left(O c p_{o}+V c p_{v}+C c p_{c}\right)-D \leq 0,15\left(O c p_{o}+V c p_{v}+C c p_{c}\right) \\
& O c p_{o}+V c p_{v}+C c p_{c} \geq D \\
& O c t_{o}+V c t_{v}+C c t_{c} \leq O d
\end{aligned}
$$




$$
\begin{aligned}
& c p_{o} \leq 44 \\
& c p_{v} \leq 20 \\
& c p_{c} \leq 4 \\
& C \leq 2
\end{aligned}
$$

The reduction of vehicles was made so that there are cars available to transport passengers to the most distant destinations, in these cases where demand is lower, but in the same way there must be availability of vehicles to carry out transportation when necessary. The

\begin{tabular}{|c|c|c|c|c|c|c|c|c|c|}
\hline \multicolumn{2}{|c|}{$\begin{array}{c}\text { Among of } \\
\text { each type of } \\
\text { vehicle }\end{array}$} & Capacity & Total & $\begin{array}{c}\text { Daily } \\
\text { demand }\end{array}$ & $\begin{array}{c}\text { Daily } \\
\text { Bdudget }\end{array}$ & $\begin{array}{l}\text { Transport } \\
\text { cost }\end{array}$ & Cost & $\begin{array}{c}\text { Total of } \\
\text { empty } \\
\text { seat }\end{array}$ & $\begin{array}{c}\text { Empty } \\
\text { seats } \\
\text { max } \\
\end{array}$ \\
\hline Bus & 2 & 44 & 0 & \multirow{4}{*}{110} & \multirow{4}{*}{$\$ 1.013,51$} & $\$ 324,32$ & $\$ 648,65$ & \multirow{4}{*}{2} & \multirow{4}{*}{17} \\
\hline Van & 1 & 20 & 120 & & & $\$ 162,26$ & $\$ 162,26$ & & \\
\hline Car & 1 & 4 & 4 & & & $\$ 72,97$ & $\$ 72,97$ & & \\
\hline Total & 4 & $\begin{array}{c}\text { Total of } \\
\text { passangers }\end{array}$ & 112 & & & Total & $\$ 883,88$ & & \\
\hline
\end{tabular}
reduction was four cars available for two and is represented in equation (8). In Table 4 the results of simulation 3 are shown.

Table 4: Simulation Result of Model 2

What differs from the previous model is the number of cars available to transport the passengers and the solution found by Solver was identical. This result, together with the average daily demand, leads to believe that there is room to work on the restriction of available cars, and with that, reduce the fixed costs of transportation.

\subsection{Model 4: Minimization of Costs Without Using Own Fleet}

In Model 4, the cars are not considered for the optimal mix, this is due to the reduction of the number of owned vehicles so that the fixed costs are reduced, as is the case for drivers.

$$
\operatorname{Min} z=O c t_{o}+V c t_{v}
$$

Subject to:

$$
\left(O c p_{o}+V c p_{v}\right)-D \leq 0,15\left(O c p_{o}+V c p_{v}\right)
$$


DOI: 10.14807/ijmp.v12i8.1510

$O c p_{o}+V c p_{v} \geq D$

$O c t_{o}+V c t_{v} \leq O d$

$c p_{o} \leq 44$

$c p_{v} \leq 20$

$O, V, C \geq 0$ and integer

In this model the car restrictions were eliminated, also the decision variable and cost constant that symbolized it. It is important to clarify that this model does not have the function to exclude all the owned fleet, but to reduce it and the available cars are only used to transport passengers to the most distant destinations that are not being considered in the models here presented. In Table 5 the results of simulation 4 are pointed out.

Table 5: Simulation Result of Model 4

\begin{tabular}{|c|c|c|c|c|c|c|c|c|c|}
\hline \multicolumn{2}{|c|}{$\begin{array}{l}\text { Among of } \\
\text { each type } \\
\text { of vehicle }\end{array}$} & Capacity & Total & $\begin{array}{c}\text { Daily } \\
\text { demand }\end{array}$ & $\begin{array}{l}\text { Daily } \\
\text { Budget }\end{array}$ & $\begin{array}{c}\text { Transport } \\
\text { cost }\end{array}$ & Cost & $\begin{array}{c}\text { Total of } \\
\text { empty } \\
\text { seat }\end{array}$ & $\begin{array}{c}\text { Empty } \\
\text { seats max }\end{array}$ \\
\hline Bus & 0 & 44 & 0 & \multirow{4}{*}{110} & \multirow{4}{*}{$\$ 13875$} & $\$ 324,32$ & $\$ 0,00$ & \multirow{4}{*}{10} & \multirow{4}{*}{18} \\
\hline Van & 6 & 20 & 120 & & & $\$ 162,26$ & $\$ 972,97$ & & \\
\hline Car & 0 & 0 & 0 & & & $\$ 72,97$ & $\$ 0,00$ & & \\
\hline Total & 6 & $\begin{array}{c}\text { Total of } \\
\text { passangers }\end{array}$ & 120 & & & Total & $\$ 972,97$ & & \\
\hline
\end{tabular}

As a result, there was an increase both in the number of empty sits and in the daily cost of transportation. This result shows that, since daily demand is variable and may not be an ideal number for passenger allocation only in higher capacity vehicles, it is good that at least $1 \mathrm{car}$ is available for this route so that it won't be necessary hiring a large vehicle for a small amount of passengers therefore raising costs and reducing transportation efficiency.

\section{DISCUSSION}

When analyzing the results, it is concluded that the model that best suits the presented problem is the one of costs minimization, since the one of vehicles presented higher costs. Possibly the model that minimizes the vehicles would bring better results if the vehicles were not outsourced, but of the PMPG.

It has also been found that it is not effective to rely only on outsourced transportation, it is necessary to use owned vehicles for economy. This issue is related to a particularity of the problem, in which it is not possible to change the number of passengers that need transportation, since the consultations and appointments are scheduled, which makes a more 
INDEPENDENT JOURNAL OF MANAGEMENT \& PRODUCTION (IJM\&P)

http://www.ijmp.jor.br

v. 12, n. 8, November-December 2021

ISSN: $2236-269 X$

DOI: 10.14807/ijmp.v12i8.1510

efficient control impossible, such as traveling only 3 times a week, which would reduce costs. Another important factor that needs to be considered is the inability to limit the amount of passengers, because health is a basic citizen's need, time is crucial; and it must be priority to meet the demand without providing restrictions to the patients use.

In the midst of these particularities, optimization is necessary for this transportation to be carried out in the most effective way possible. By not wasting financial resources for possible poor planning of these transports allows this economy to be better applied in other sectors of health or even in transportation, increasing the service capacity for users.

With the four models developed and the results obtained, there is a space to make a new model that is even better suited to the problem. This model would be the same as Model 3, with the only difference in the restriction of maximum quantity of cars that can be used in the route, one suggestion for the problem would be to consider only one vehicle out of the total of 4 available. In addition, it is possible to reduce 1 car from the current fleet, so the total would be 3 , in which only 1 could be used for the route to Curitiba and cities of the region and 2 would be available for long distance travel. With these improvements, there would be a reduction in fixed costs, as it would only be necessary 5 drivers instead of the current 6 besides, of course, the costs of the vehicle's maintenance. It is also possible to consider the relocation of the car and driver to meet other demands of the 3rd region.

The scenario chosen to carry out the simulations was that of daily planning, this is due to the daily oscillation of the quantity of passengers, so to carry out a daily transport planning allows a better optimization of the transportation. From the results obtained, for example, maintaining an average of 110 passengers per day, the average monthly cost would be \$20.000.00 already considering a car and a driver less, the average is currently \$ 22378 without the ambulances' cost. This shows significant savings, these funds could be reinvested to improve service to the population. The PMPG currently uses this model to plan the daily demand for patient travel.

However, for pandemic times, it is suggested to analyze the transport of patients in a safer way. As there is no possibility of making a trip for each patient, the option of transporting with larger cars is pointed out. In this transport, patients stay at a greater distance from others, use personal protective equipment, be accompanied by a health team, as it is not allowed to accompany in hospitals in times of pandemic and the vehicle is cleaned every time, so by choosing the Minimization of the Quantity of Vehicles option. 
DOI: 10.14807/ijmp.v12i8.1510

\section{CONCLUSION}

The work accomplished with the proposed objective, the patient flow optimization was achieved, is to develop, from the data collection, a linear programming problem that optimizes the logistics of patients from the 3rd Region of Health from the state of Paraná, seeking to use the available resources efficiently. However, the results obtained were favorable and open doors for the development of new works.

The developed model is being used and allows to improve the transportation planning of patients and caregivers for home care. However, health logistics planning must be continuous and changeable at the same time. Because, at any time, the demand can change and the type of illness of the patients and the location of the care as well. As an example, patients with COVID 19 today.

Thus, there is room for the development of more complex works, where there is greater detail of information, allowing better management of the public system, we propose the study with the p-center method, p-medians, joint coverage to evaluate the best distribution of patients from regions. to other health centers. Also study about the internal logistics of Health Unic System (HUS) patients, aiming to optimize the fleet of vehicles moving within cities, as well as in the city's own health centers, in order to minimize the time of service to users.

The study has brought to light the importance of conducting such studies and projects. By applying optimization tools, the resources available for public management would be improved, avoiding waste and allowing new investments, expanding capacity and changing the quality of care offered to the population.

However, reinforce the importation of planning and studies of logistics in the health area, mainly in the public area, as this can lead to the well-being of people with less financial conditions to access health and, mainly, to avoid aggravating diseases and deaths.

\section{REFERENCES}

Aragão, F. V., Zola, F. C., Marinho, L. H. N., De Genaro Chiroli, D. M., Junior, A. B., \& Colmenero, J. C. (2020). Choice of unmanned aerial vehicles for identification of mosquito breeding sites. Geospatial Health, 15(1).

Babazadeh, R., Jolai, F., Razmi, J., \& Pishvaee, M. S. (2014). Developing a robust programming approach for the responsive logistics network design under uncertainity. International Journal of Industrial Engineering, 21(1), 1-17.

Ballou, R. H. (2001). Supply Chain Management: Business Planning, Organization, and Logistics. 4. ed. Porto Alegre: Bookman. 
DOI: 10.14807/ijmp.v12i8.1510

Ballou, R. H. (1993). Business logistics. São Paulo: Atlas.

Barbosa, K. S. S. (2015). Hospital pharmacy management: optimization of quality, productivity and financial resources. Journal Health and Development, 7(4).

Bergquist, R., \& Stensgaard, A. S. (2020). Covid 19: End of the beginning? Geospatial Health, 15(897), 6-10.

Bindman, A. B. (2013) The evolution of health services research. Editorial. Health Services Research, 48(2), 349-353.

Brasil. (2006). Ministry of health. Solidarity and cooperative regionalization. Available at: <http://bvsms.saude.gov.br/bvs/publicacoes/regionalizacao2006.pdf>. Acess mai 2017.

Careta, C. B. (2013). Performance measurement of logistics activities: multiple case study in university teaching hospitals. 2013, p. 184 Thesis (Doctorate in Production Engineering). Sao Carlos School of Engineering, University of Sao Paulo, Sao Carlos.

Chiroli, D. M. G., Rodrigues, H. F., \& Mayerle, S. F. (2016). Problem Truck driver scheduling and routing HOS: A study of scientific production. Espacios. 37(04), 17. Available at: https://www.revistaespacios.com/a16v37n04/16370418.html

Coêlho, E. P. F. (2010). Dispensing logistics in the public health network. In: III Congresso Consad de Gestão Pública, 2010, Curitiba. Painel. Curitiba: Escola de Gestão, 2010. 3-4. Available at:

$<$ http://www.escoladegestao.pr.gov.br/arquivos/File/Material_CONSAD/paineis_III_congres so_consad/painel_8/logistica_de_dispensacao_n a_rede_de_saude_publica.pdf $>$. Acesso em: 20 maio 2017.

Dussault, G. (1992). The Management of Public Health Services: Characteristics and Requirements. Public Administration Magazine, Rio de Janeiro, 26(2), 01-19.

Fitzsimmons, J. A., \& Fitzsimmons, M. J. (2010). Service administration: operations, strategy and information technology. Ponto Alegre: Bookman.

Gao, X., Zhou, Y., Amir, M. I. H., Rosyidah, F. A., \& Lee, G. M. (2017). A hybrid genetic algorithm for multi-emergency medical service center location-allocation problem in disaster response. International Journal of Industrial Engineering, 24(6).

Gul, M., \& Guneri, A. F. (2016). Planning the future of emergency departments: Forecasting ED patient arrivals by using regression and neural network models. International Journal of Industrial Engineering, 23(2).

He, Y., \& Liu, N. (2015). Methodology of emergency medical logistics for public health emergencies. Transportation Research, 178-200.

Infante, M., \& Santos, M. A. B. (2007). The organization of public hospital supply from the production chain: a logistical approach to health. Science and Public Health, 12(4).

Landry, S., Beaulieu, M., \& Roy, J. (2016). Strategy deployment in healthcare services: A case study approach. Technological Forecasting \& Social Change.

Lapierre, S. D., \& Ruiz, A. B. (2007). Scheduling logistic activities to improve hospital supply systems. Computers \& Operations Research, 34, 624-641.

Lent, W. A. V., Sanders, E. M., \& Harten, W. H. V. (2012). Exploring improvements in patient logistics in Dutch hospitals with a survey. BMC Health Services Research, 12(232).

Liew, M. F., Siow, W. T., Ying, W. Y., \& See, K. S. (2020). Safe patient transport for COVID-19. Critical Care, 24(94), 1-3. 
Liu, R., Xie, X., \& Garaix, T. (2014). Hybridization of tabu search with feasible and infeasible local searches for periodic home health care logistics. Omega, (47), 17-32.

Lunz, J., Hinsdale, L., King, C., Pastush, R., Buenvenida, M., \& Hamon, M. (2016). The coordination of allocation: Logistics of kidney organ allocation to highly sensitized patients. Human Immunology.

Masmoudi, M., Chalgham, M., \& Houria, Z. B. (2018). Fuzzy decision making for inpatient boarding: case of a tunisian hospital. International Journal of Industrial Engineering: Theory, Applications and Practice, 25(3).

Mathias, R. V., Azevedo, B. M., \& Campos, F. L. S. (2015). Health services logistics: concepts, definitions and challenges. In: National Meeting of Production Engineering, 35, 2015. Fortaleza, CE. Anais... Fortaleza, CE: Abepro. p. 2 - 5. Available at: <http://www.abepro.org.br/biblioteca/TN_STO_206_222_27865.pdf>. Acess mai 2017.

Paraná (2015). Secretaria de Estado da Saúde do Paraná. Plano Diretor de

Regionalização. Disponível em <http://www.saude.pr.gov.br/arquivos/File/00__NDS/PDR_2015.pdf>. Acess: mai 2017.

Piccirillo, I. N., Chiroli, D. M. D. G., \& De Mello, L. T. C. (2016). Routing with sweeping method: a proposal to improve the formatting loads, reduce costs and meet customer. Revista ESPACIOS, 37(4).

Raimundo, E. A., Dias, C. N., \& Guerra, M. (2014). Logistics of Medicines and Materials in a Public Hospital of the Federal District. Journal of Hospital Administration and Health Innovations.

Rodrigues, S. L., \& Sousa, J. V. O. (2014). Hospital logistics: an exploratory study on processes in drug purchasing management. Article Proceedings of the $\mathbf{X}$ National Congress of Excellence in Management. August. Rio de Janeiro, 2014.

Scarpin, C. T., Steiner, M. T. A., Dias, G. J. C., \& Neto, P. J. S. (2007). Health service optimization in the state of Paraná: patient flow and new hierarchical configurations. Journal Management and Production, 15(2), 275-290, maio-ago.

UN. United Nations, (2015). Sustainable Development Goals. Available at: https://www.un.org/sustainabledevelopment/sustainable-development-goals/. Acess mar. 2018.

Vanvactor, J. D. (2011). Strategic health care logistics planning in emergency management. Disaster Prevention and Management, 21(3), 299-309.

Villa, S., Prenestini, A., \& Giusepi, I. (2014). A framework to analyze hospital-wide patient flow logistics: Evidence from an Italian comparative study. Health Policy, 20(115), 196-205.

Ying, K-C., \& Kittipittayakorn, C. (2018). Combining discrete event and agent-based simulation for reducing draftees waiting time in physical examination centers. International Journal of Industrial Engineering, 25(2).

Yousuf, B., Sujatha, K. S., Alfoudri, H., \& Mansurov, H. (2020). Transport of critically ill COVID-19 patients. Intensive Care Med, 46(5), 1-3. 